\title{
HITHER AND YON
}

DOUGLAS W. LEWIS, formerly at McGILL UNIVERSITY, has accepted a position in the Department of Geology, UNIVERSITY of CANTERBURY, Christchurch, New Zealand where he will teach sedimentology.

MAURICE SCHWARTZ of COLUMBIA UNIVERSITY is spending the summer along the coast of Nova Scotia where he can study tidal cycle sedimentology by fluorescent tracers and profiling techniques.

FRANK T. MANHEIM of WOODS HOLE OCEANOGRAPHIC INSTITUTION visited

Lake Charlotte, N.S. famous for its manganese nodules. He is gathering data for a comparative geochemical study of nodules from various environments in different parts of the world.

WILLIAM R. CHURCH of the UNIVERSITY OF WESTERN ONTARIO is spending the summer in Newfoundland where he is continuing studies in the vicinity of Baie Verte.

Staff members, graduate and undergraduate students of the INSTITUTE OF OCEANOGRAPHY, Dalhousie University spent the month of May 1965 on the CNAV SACKVILLE. The first phase of the cruise was spent sampling sediments and microfauna on Sable Island and Banquereau Banks as part of a major I.O.DAL. MARINE GEOLOGY GROUP project: Submarine Geology of the Scotian Shelf and Slope. N. JAMES, F. MEDIOLI, and D.J. STANLEY and students spent 3 weeks sampling and completing a geological survey of Sable Island and vicinity.

G. DRAPEAU, J. MILLER, D.J.P. SWIFT, and I.O.Dal. students spent the 2nd phase of the cruise in the Bay of Fundy - Minas Basin area. The purpose of this study is to determine the amount and types of suspended sediment being transported and the effect of tidal currents on this transport.

Several staff of the BEDFORD INSTITUTE OF OCEANOGRAPHY have just returned from cruise and others are at sea or preparing for a cruise:

G.A. BARTLETT is presently on a study of benthic foraminiferal ecology of inshore waters around the Atlantic Provinces. He is using a speed boat and is undertaking much of his sampling by means of SCUBA diving.

A.C. GRANT returned from sampling operations over the Arctic Ocean in April and has just completed trial runs with a new sparker system which was used on a sub-bottom profiling project off southwest Newfoundland. He is currently preparing for more of this work to take place in Hudson Bay this summer.

L.H. KING completed another cruise aboard "Kapuskasing" over the Continental Shelf southeast of Halifax. He is presently undertaking 
research on these sediments in which he is investigating the organic geochemistry of the deposits.

J.I. MARLOWE returned from an earlier cruise aboard "Kapuskasing" from which he sampled the Continental Slope off Sable Island.

B.R. PELLETIER returned from another season on bottom studies of the Arctic Ocean. He is presently co-ordinating the preparation for a combined geophysical, geological, oceanographic cruise in to Hudson Bay in July 1965, which will be supported by two ships (C.S.S. HUDSON and M/V THERON), aircraft (R.C.A.F. North Star and chartered Hiller aircraft), small sea craft (two motor launches and landing barge), and Decca Navigation. This project will involve the participation of eight divisions of government and six universities.

G? VILKS is undertaking a new research program on productivity aspects in the Bras d'Or Lakes. He is using a launch for his platform and is carrying out the program in co-operation with Dalhousie University .

F.J.E. WAGNER is preparing for a cruise in to Hudson Bay. She will be examining molluscs primarily.

PROFESSOR K. HOOPER of CARLETON UNIVERSITY, Ottawa, completed his sabbatical leave at NEW YORK UNIVERSITY and is now continuing his field work from last year involving a study of the benthic fauna in the Gaspe region of the St. Lawrence River and Gulf. Part of his collections will be made on land in the Ancient Champlain Sea deposits.

K.M. KRANCK completed detailed analyses of material collected from the Richibucto area of Northumberland Strait. She is presently engaged on an extended sedimentologica 1 - physiographic - geological study of the northern part of Northumberland Strait and is undertaking this program by means of a hydrographic launch.

P. WISE, who will be attending JOHN HOPKINS UNIVERSITY next fa11, is undertaking a sedimentological analyses of recent Arctic sediments collected by the CANADIAN HYDROGRAPHIC SERVICE. Her work is being carried out in the geological laboratories of CARLETON UNIVERSITY. She is also supervising the laboratory program for Professor HOOPER. This is a co-operative program with Carleton University.

C. YORATH joined L.H. KING aboard "Kapuskasing" for a cruise over the Scotian Shelf north of Halifax. He collected bottom material for his doctoral program involving a combined sedimentological - foraminiferal ecologicai study of this area. This is a co-operative program with QUEEN'S UNIVERSITY.

CHARLES PHIPPS of the UNIVERSITY OF SYDNEY, Australia is presently involved on a sedimentological and geochemical study of sediments collected on the Continental Shelf, east of Halifax in conjunction with the program undertaken by L.H. KING. 